\title{
Preparation of a Learning Module for Entrepreneurship Course at Economic Education Study Program of Faculty of Teacher Training and Education Sriwijaya University
}

\author{
Firmansyah $^{1} \&$ Rusmin $^{1}$ \\ ${ }^{1}$ Teacher Training Education, Sriwijaya University, Palembang, Indonesia \\ Correspondence: Firmansyah, Teacher Training Education, Sriwijaya University, Palembang, Indonesia. E-mail: \\ firman0807@gmail.com
}

Received: November 16, 2017

Accepted: January 12, 2018

Online Published: April 23, 2018

doi:10.5539/ies.v11n5p14

URL: https://doi.org/10.5539/ies.v11n5p14

\begin{abstract}
The objective of this study was to prepare teaching materials in the form of entrepreneurship learning module to be used as a handbook in the classroom learning process. Entrepreneurship lecture of study program at FKIP UNSRI has various material differences delivered in lecturing activity. One of the objectives to be achieved in this study was to obtain a general description of the entrepreneurship learning materials that should be the subject. 14 materials obtained from the results of data processing from questionnaires given to lecturers of entrepreneurship courses were as follows: the scope of entrepreneurship, determination of ideas and entrepreneurial opportunities, business plan, innovation and creativity in entrepreneurship, the concept of management in entrepreneurship, marketing strategy and the concept of Break Event Point (BEP), subject of entrepreneurial ethics, entrepreneurial mindset, competitive strategy, motivation theory in entrepreneurship, risk management of customer behavior and the path to successful entrepreneurship. The materials obtained from this data processing were then used as a guide for the preparation of entrepreneurship learning modules starting from the preliminary study, in the form of needs analysis of the learning module and found out that entrepreneurship learning module needed to be prepared to support the achievement of learning objectives. The next step was to map the module based on the syllabus to obtain the title of the module developed, followed by the preparation of the opaque module and the module writing stages containing the introductory section (introduction, table of contents, list of figures, list of tables, description, module usage guide, glossary), section of learning materials (14 Materials) and references. Finally the entrepreneurship learning module for the students was prepared.
\end{abstract}

Keywords: development module, learning module, entrepreneurship, materials of entrepreneurship

\section{Introduction}

Teaching materials are all forms of materials that can be used by educators as a tool in carrying out teaching and learning activities in the class. One of the simplest teaching materials that can be used to help the learning process is a module. A module is a book written aiming to help learners learn independently with or without teachers' guidance, so that the module contains at least about the basic components of the teaching materials mentioned previously (Zulkarnain, 2009, p. 41).

Providing teaching materials in the form of modules will make it easier for students to understand the planned learning materials. Another consideration is the characteristics of the learner. Due to several factors, not all teaching materials developed by other institutions are suitable for all learners. This course aims to provide understanding and skills of various concepts and practices of entrepreneurship. The realistic condition is that entrepreneurship courses are general courses with the same purposes that exist in almost every study program at the faculties of Sriwijaya University. Nevertheless, the result of a short discussion of the researchers with some lecturers of this course in the scope of study program of faculties and in the lecturers' forum showed that they have different material structures depending on the scientific point of view of the lecturers.

This heterogeneity is both an obstacle and an opportunity to be studied. One of the things that can be utilized in this diversity according to the researchers is to summarize the ideas and inputs of lecturers from various faculties into a module of entrepreneurship learning module from various perspectives of entrepreneurship lecturers.

The module created based on the perspective and thinking of cross-scientific study is expected to contribute in 
improving the quality of classroom learning through the presentation of quality teaching materials. In an ideal condition, entrepreneurship course is one of the courses that provide understanding and train students' skills to cultivate entrepreneurial talent in order to create entrepreneurial students oriented as employers and not just job seekers.

The brief description makes the researchers interested in arranging teaching materials in the form of a module. Therefore, the authors feel the need to arrange teaching materials in the form of self-developed modules based on the input of the lecturers and adjusted to the characteristics of students who have a valid material content in the hope of obtaining maximum learning results.

\section{The Formulation of the Problems}

Based on the description on the background, the issues to be studied were as follows:

1) What materials should be the learning subjects of entrepreneurship courses?

2) How to prepare the learning module of entrepreneurship course based on the inputs from its lecturers of FKIP faculty at Sriwijaya University?

\section{Literature Review}

\subsection{Learning Concepts}

Learning can be defined as a complex process that happens to everyone and lasts a lifetime. One sign that a person has learned is a change of behavior within himself, the change concerns both the cognitive and psychomotor changes as well as the values and attitudes (affective), Sadiman et al. (2007, p. 2), then Hamalik (2008, p. 57) states that learning is a neat combination that includes human elements, materials, facilities, equipment, and procedures that affect one another to achieve learning objectives.

\subsection{Development in the Learning Process}

Development is the process of translating design specifications into physical form (Seels \& Richey, 1994, p. 38). According to Sadiman et al. (2007) there are four domains in Development:

1) Print technology is the means of producing and distributing material by mechanical or electronic machinery to produce messages in the form of auditory and visual.

2) Audio visual technology

3) Computer-based technologies are ways to produce and distribute material using sources based on a microprocessor.

4) Integrated technology is the means of producing and distributing material that involves some forms of media guided by the computer. Most sophisticated learning techniques involve multiple forms of media in an integrated manner with computer control. Learning products can be in the form of hardware and software.

Thus, it can be concluded that the instructional design producing the instructional materials in the form of modules can be included in the category of printed technology learning design in the development area; it is the focus of this study to be conducted. Then, the development of teaching materials to be focused on is the development of teaching materials in the form of modules.

\subsection{The Nature of the Teaching Materials}

In principle, teaching materials are different with learning resources and learning media. According to Sadiman et al. (2007) learning resources is everything that can be used for learning like people, objects, messages, materials, techniques and background.

\subsection{Module}

Definition of Module: A module is a form of teaching material arranged completely and systematically containing a set of planned learning experience and designed to help learners master specific learning objective. A module at least contains learning objectives, materials, and evaluation (Daryanto, 2013).

\subsection{Characteristics of a Learning Module}

According to Arikunto (2006), a learning module has four inherent features as follows:

1) Have a sentence that is able to explain itself.

2) Can be studied by students according to the speed of their own learning.

3) Can be studied by students according to the time and place chosen. 
4) Able to make students actively do something at the time of study, such as doing exercises, tests or practical activities.

\subsection{Steps for Composing a Module}

The steps for preparing a module are as follows (Daryanto, 2013):

a. An analysis of Module Needs

An analysis of module needs is an activity of analyzing syllabus and RPP to obtain module information needed by learners in studying the competence programmed. The name or title of the module should be adjusted to the competencies contained in the syllabus and RPP.

b. Preparing module maps

A map of module needs is needed to determine the number of modules to be written and the sequence of modules. The module sequence is necessary in determining the writing priority. It is started with SAP and syllabus analysis, needs analysis and analysis of learning resources.

c. Module Design

Module writing design here is the SAP and syllabus that have been prepared. It contains learning strategies and media used, outline of learning materials and assessment methods and tools.

d. Determining the contents of the module

The contents of the module is determined on the basis of basic competencies, subjects or learning experiences contained in SAP and Syllabus so that the module compiled can be sequential and well planned.

e. Writing a module

\section{The Objectives of this Study}

The objectives of this study were:

1) To find out what materials should be the subjects of learning entrepreneurship courses.

2) To compose learning modules for entrepreneurship courses based on inputs from the lecturers of entrepreneurship courses of FKIP at Sriwijaya University.

\section{Method of Research}

This study is a form of research and development aimed at producing Entrepreneurship Learning Module for Economic Education Study Program, categorized as research and development by referring to Borg and Gall R \& D cycle model (with modification at expert review stage) but is limited to the validation stage of the expert in the cross-departmental material aspects and will be revised in further study.

\subsection{Subject and Place of Study}

This study was conducted in the academic year of 2017-2018. The subjects of the study were lecturers of entrepreneurship courses in FKIP and they also served as expert reviewers at Sriwijaya University.

\subsection{Research Procedure}

The research procedure adopted in this study followed the steps in the development research described briefly in the following figure. 


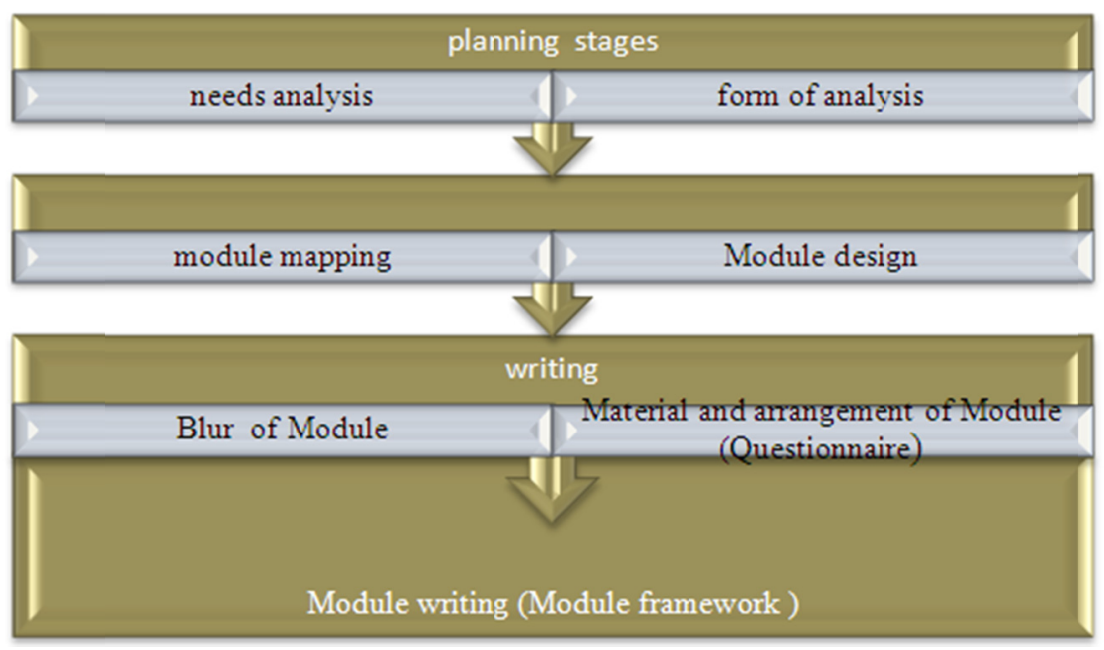

Figure 1. Diagram of development procedures of entrepreneurship learning module

\subsection{Techniques of Data Collection}

Data collection in this study includes expert validations, interviews, observations, student response questionnaires and tests. It can be seen in the table below:

Table 1. Techniques of data collection

\begin{tabular}{lccc}
\hline No & Techniques of Data Collection & Instrument & Data \\
\hline \multirow{2}{*}{1} & Questionnaires/Interviews & Questionnaires & Feedback and Suggestions regarding module compiler \\
2 & (Guttman/Likert) & Sheets & materials \\
\hline
\end{tabular}

\subsection{Technique of Data Analysis}

The data obtained were analyzed with the following steps:

1) Analysis of Data Questionnaire

Questionnaires givento the experts in this process was in the form of questionnaires by using the Guttman scale to select the contents of the module with two options that convinced the researchers to the assurance of expert opinion review that was Yes and No, then sought the average score using the following formula:

$$
R=\frac{\sum_{\mathrm{i}=1}^{\mathrm{n}} \mathrm{Vi}}{\mathrm{n}}
$$

Where:

$\mathrm{R}=$ the average result of the validator's assessment

$\mathrm{Vi}=$ score of assessment results from the $\mathrm{i}$-th validator

$\mathrm{n}=$ number of validator

The data was then analyzed by percentage technique based on the number of expert choices.

$$
\mathrm{P}=\frac{F}{N} \times 100 \%
$$

Note:

$\mathrm{P}=$ Percentages searched for each

$\mathrm{f}=$ Frequency of answers obtained

$\mathrm{N}=$ Frequency of all answers

$100=$ Fixed numerator 


\section{Research Results and Discussion}

\subsection{Research Results}

Here are the results of questionnaires in the form of Guttman scale obtained from the entrepreneurship lecturers:

Table 2. The calculation results of the percentage of entrepreneurship lecture materials based on the results of reviewers' inputs

\begin{tabular}{|c|c|c|}
\hline Sequence & Materials & Persentase Obtained \\
\hline 1 & The Scope of Entrepreneurship & $90 \%$ \\
\hline 2 & Determination of Entrepreneurial Ideas and Opportunities & $90 \%$ \\
\hline 3 & Business Plan & $80 \%$ \\
\hline 4 & Innovation and Creativity in Entrepreneurship & $80 \%$ \\
\hline 5 & The Concept of Management in Entrepreneurship & $80 \%$ \\
\hline 6 & Marketing Skills & $80 \%$ \\
\hline 7 & The Concept of BEP & $80 \%$ \\
\hline 8 & EntrepreneurialEthics & $70 \%$ \\
\hline 9 & Entrepreneurial Mindset & $70 \%$ \\
\hline 10 & Competitive Strategy & $70 \%$ \\
\hline 11 & Motivation Theory in Entrepreneurship & $70 \%$ \\
\hline 12 & Risk Management & $70 \%$ \\
\hline 13 & Customer Behavior & $60 \%$ \\
\hline 14 & The Road to Successful Entrepreneurship & $60 \%$ \\
\hline 15 & Leadership & $50 \%$ \\
\hline 16 & Marketing Plan & $50 \%$ \\
\hline 17 & Characters That Must be Owned by the Entrepreneurs & $40 \%$ \\
\hline 18 & The Plan of the Entrepreneurial Organization & $40 \%$ \\
\hline 19 & Perspective of Entrepreneurship & $30 \%$ \\
\hline 20 & Reasons, Factors and Capital of Entrepreneurship & $30 \%$ \\
\hline 21 & Financial Plan & $30 \%$ \\
\hline 22 & Attitude and Behavior of Entrepreneurship & $20 \%$ \\
\hline 23 & Entrepreneurial Financing & $20 \%$ \\
\hline 24 & Increase in Business Productivity & $20 \%$ \\
\hline 25 & Entrepreneurial Trends & $20 \%$ \\
\hline 26 & Branding & $10 \%$ \\
\hline 27 & Communication and Interpersonal & $0 \%$ \\
\hline 28 & The Process of Managing, Developing and Ending Entrepreneurship & $0 \%$ \\
\hline
\end{tabular}

The materials were selected for only 14 meetings based on the percentage results since another twice meetings were used for a midterm test (UTS) and final test (UAS). The 14-meeting materials were used as the materials for the preparation of entrepreneurship lecture module.

The preparation of the module was carried out after the materials had been obtained from the discussion results of the lecturers. It is described as follows.

1) The Results of the Introduction Phase

\section{a. Needs Analysis}

Based on the results of the needs analysisabove, it was concluded that it was necessary to compile an entrepreneurship learning module in accordance with the input of lecturers designed for the needs of economic students of FKIP based on each capability to be achieved. After the needs analysis was done, the material analysis and characteristics of the learners were carried out. It aimed to simplify the selection of basic competencies in entrepreneurial learning that would be the material for the development of this module.

Based on this, it was concluded that it was important to develop entrepreneurship learning module for the students in order to create a fun learning process with optimal learning outcomes.

\section{b. Arrangement of Module Map}

At this stage the preparation of module maps was carried with the following scheme: 


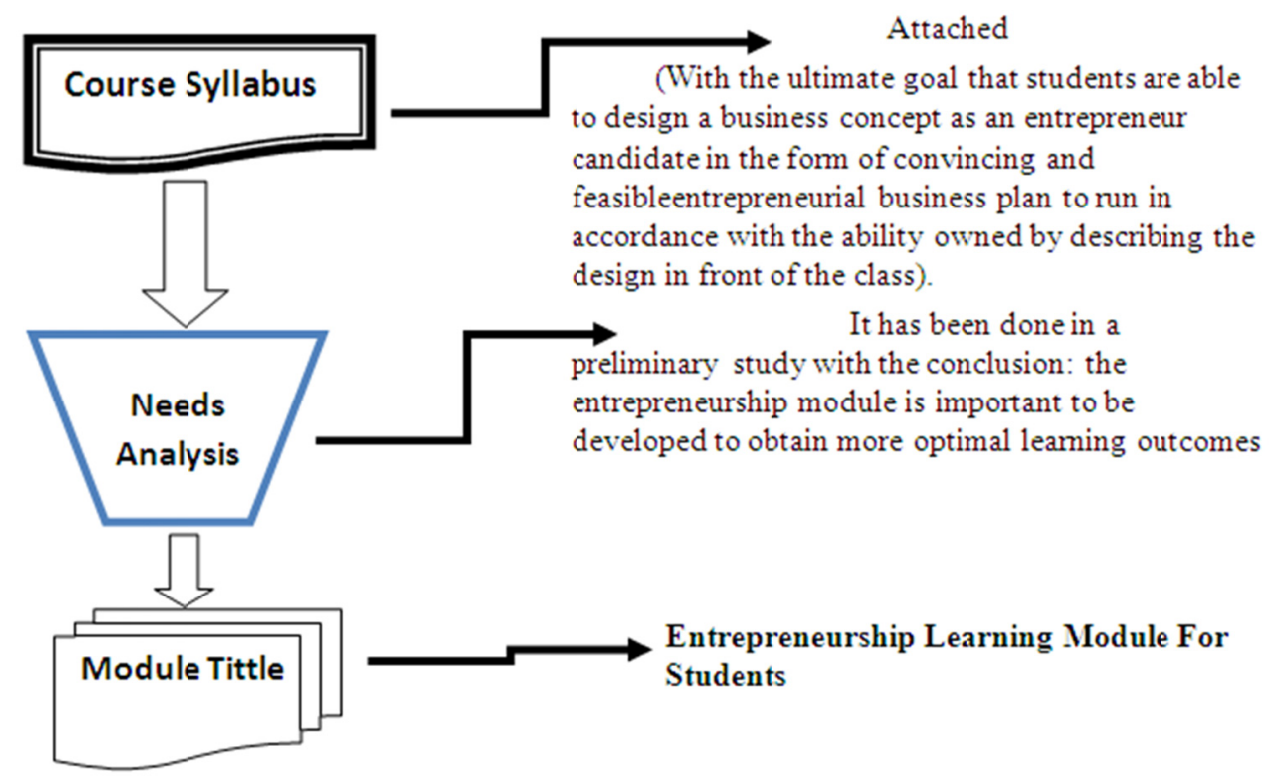

Figure 2. Scheme of entrepreneurship module Map

\section{c. Design (Opaque Module)}

Having obtained lecture module map, then the design can be drawn up in the opaque form of the entrepreneurship module described in the following scheme:

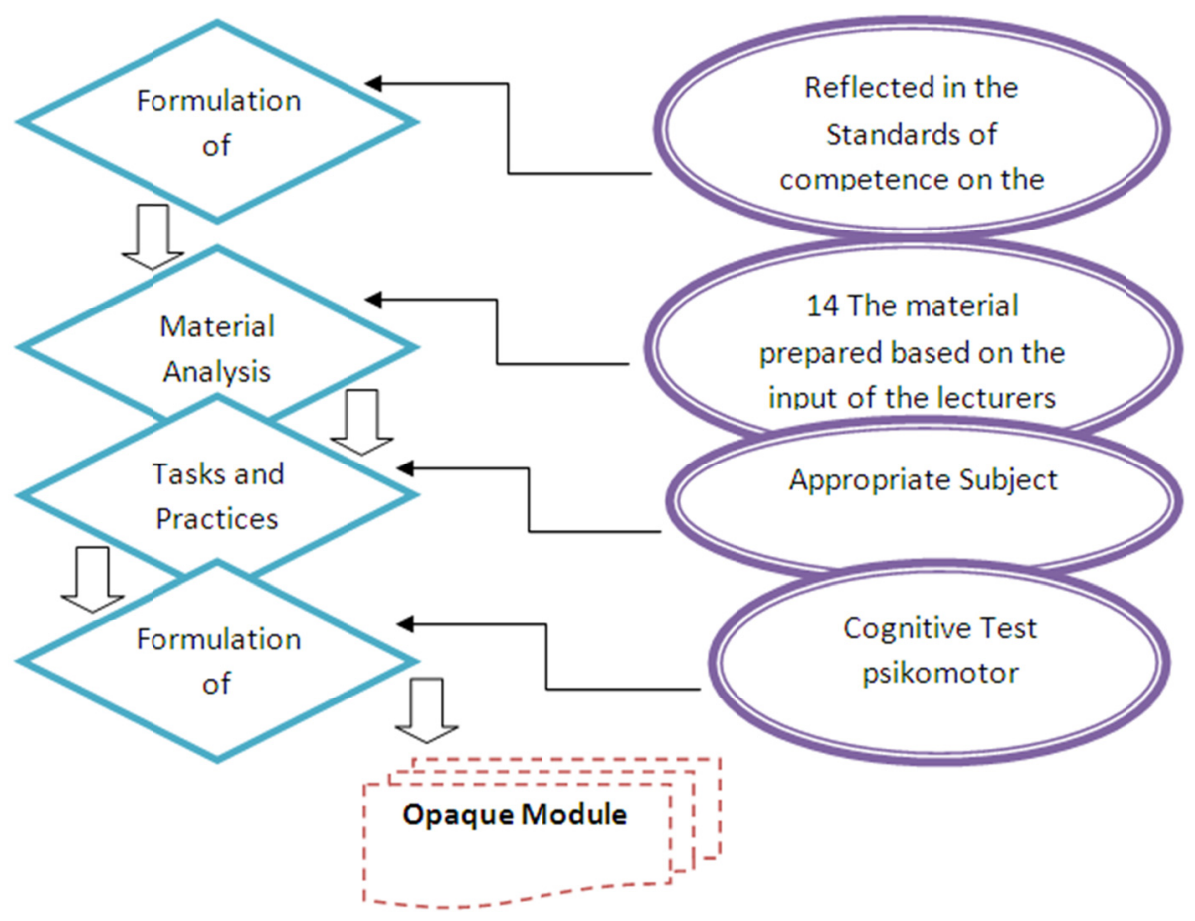

Figure 3. Opaque Module

\section{d. Module Writing}

In this process the format of the module structure designed to be the learning module of entrepreneurship course has been adjusted to the consideration of class conditions and activities designed by the lecturer, the outline is as follows: 
A. Composition of entrepreneurial modules

I. Introduction

- Preface

- Contents

- $\quad$ List of Figures

- $\quad$ List of Tables

- Description

- Instruction for Module Use

- Glossary

II. Learning

Materials in learning (14 materials)

- Basic Competencies

- Description of Learning Materials

- $\quad$ Formative Test

\section{References}

\subsection{Discussion of Research Results}

In this research activity the first thing to be answered was which materials should exist in entrepreneurship courses, it was based on the condition of the field where the material was presented in the learning process in each study program within the Faculty of Teacher Training and Education (FKIP) does not have uniformity. This was due to different perception, the scientific background of the lecturer, the color of the study program and various other things, the result of the questionnaire given to the respondent was the lecturer of entrepreneurship subject from the various study program obtained 14 materials most dominantly chosen by the respondents (entrepreneurship lecturer) as the result of ranking from 28 materials offered by researchers to be discussed in entrepreneurship class activities in the class.

The most dominant material was the scope of entrepreneurship and determining the entrepreneurial ideas and opportunities with the percentage of respondents $90 \%$, the next 4 subjects with $80 \%$ of respondents were business plan, innovation and creativity in entrepreneurship, management concept in entrepreneurship, marketing strategy and the concept of BEP and then the subject of entrepreneurial ethics, entrepreneurial mindset, competitive strategy, motivation theory in entrepreneurship and risk management obtained percentage score of $70 \%$ each, while customer behavior and the path to successful entrepreneur obtained percentage score $60 \% .14$ such materials would be used as materials in the entrepreneurship module to be developed in this research.

In this development study activity, entrepreneurship learning module for economic education students of FKIP UNSRI needs to be composed of based on the input of entrepreneurship lecturers in the faculty. The stages of the compilation of this module were carried out by referring to the book by Daryanto (2013) including:

a. The Results of the Introduction Phase

1) Needs Analysis

In general the problems encountered in the course of Entrepreneurship including:

- The existing teaching materials are generally in the form of slides and books that can not accommodate the materials according to lecturers' expectation, making the students have not been able to understand the material presented properly so that the learning outcomes were less maximum.

- Students less actively participate in the learning activities in the classroom because of the lack of learning tools, especially textbooks as the students' handbook. In learning, students are allowed to find their own literature, so that the process of learning in class often happens only in one direction.

- There are no teaching materials in the form of modules/books prepared by lecturers. This is of course a disadvantage for students because the arrangement of material and material content from the outside is not necessarily matched with the target of learning set by the lecturer in the classroom. Adjustment of the material mainly leads to the competence to be achieved after FKIP students follow entrepreneurship courses. 
The result of requirement analysis on analysis format based on the learning plan in each meeting owned by the researcher related to all aspect of standards which is expected to arise after the learning activities are:

- Able to understand the scope of entrepreneurship, entrepreneurial ethics with the concept of planting thinking change, creative thinking, and action-oriented work.

- Able to understand how to find business ideas and business opportunities on the basis of the potential of using innovation and creativity to design the business.

- $\quad$ Able to understand the concept of risk, BEP and understand how buyer behavior and know how the strategy used as a path to a successful entrepreneur

- $\quad$ Can have a high motivation in conducting business activities

- Able to design a business concept in the form of a convincing and feasible business plan that to run in accordance with the capabilities possessed by presenting their plans in front of the class.

The reality of the field has not yet set the standard set by the faculty lecturers facilitated by teaching materials in the form of modules arranged by the lecturers themselves based on the condition of the classroom, the characters, the means and various things related to learning activities in class. So the researchers concludes that the teaching materials in the form of this module need to be arranged to achieve the learning objectives.

\section{2) Module Design}

At this stage the objectives set out in the learning activities in the prepared syllabus were analyzed and re-adjusted with the input material from the questionnaire processing distributed to the respondents, the results obtained by the arrangement of 14 materials for each meeting in order of presentation based on subjective considerations of the research scientists from the first meeting until the 16th meeting in outline contains objectives, materials, tasks and evaluations so it can be written into the module form

3) Contents and Module Writing

This module contains

A. Composition of Entrepreneurial Modules

I. Introduction

- Preface

- Table of Contents

- List of Figures

- $\quad$ List of Tables

- Description

- Instructions for Module Use

- Glossary

\section{Learning}

The Scope of Entrepreneurship

- Basic Competences

- Description of Learning Materials

- Formative Test

Entrepreneurial Ethics

- Basic Competences

- Description of Learning Materials

- Formative Test

Entrepreneurial Mindset

- Basic Competences

- Description of Learning Materials

- Formative Test 
Determination of Entrepreneurial Ideas and Opportunities

- Basic Competences

- Description of Learning Materials

- Formative Test

Innovation and Creativity in Entrepreneurship

- Basic Competences

- Description of Learning Materials

- Formative Test

Motivation Theory in Entrepreneurship

- Basic Competences

- Description of Learning Materials

- Formative Test Module

Customer Behavior

- Basic Competences

- Description of Learning Materials

- Formative Test

The concept of management in entrepreneurship

- Basic Competences

- Description of Learning Materials

- Formative Test Module

Marketing Strategy

- Basic Competences

- Description of Learning Materials

- Formative Test Module

Competitive Strategy

- Basic Competences

- Description of Learning Materials

- Formative Test Module

The Concept of BEP

- Basic Competences

- Description of Learning Materials

- $\quad$ Formative Test Module

Risk Management

- Basic Competences

- Description of Learning Materials

- Formative Test Module

Business Plan

- Basic Competences

- Description of Learning Materials

- Formative Test

The Road to Successful Entrepreneurship

- Basic Competences 
- Description of Learning Materials

- Formative Test

III. References

\section{Conclusions and Suggestions}

\subsection{Conclusions}

Based on the results of research and discussion in the previous chapters, it can be concluded that:

1) Based on the results of questionnaires filled by entrepreneurshiplecturers on in the study program of FKIP UNSRI, the materials that should be discussed in the entrepreneurship learning activities in the class are as follows:
a) The Scope of Entrepreneurship
b) Determination of Entrepreneurial Ideas and Opportunities
c) Business plan
d) Innovation and Creativity in Entrepreneurship
e) The concept of management in entrepreneurship
f) Marketing Strategy dan the Concept of BEP
g) Entrepreneurial Ethics
h) Entrepreneurial Mindset
i) Competitive Strategy
j) Motivation Theory in Entrepreneurship
k) Risk Management
1) Customer Behavior and
m) Road to Successful Entrepreneurship

2) Preparation of entrepreneurship module conducted by Preliminary study stages included requirement analysis, module map, design / opaque module, module contents / framework and module writing stages so as to produce an entrepreneurship learning module ready for use for classroom learning activities.

\subsection{Suggestions}

From the research that has been done, it is suggested to the students, lecturers, institutions and other researchers as follows:

1) Learners can use the entrepreneurship module to facilitate the understanding of entrepreneurship lecture materials so as to obtain comprehension, attitude and comprehensive ability according to learning objectives of entrepreneurship.

2) Lecturers can use the entrepreneurship module in learning activities in the classroom as a selection of teaching materials that can be used to improve learning outcomes.

3) Institutions can have one of the input materials in the form of entrepreneurship module to be used as an additional material to the existing ones.

4) Other researchers can use it as a reference in the development of a better and perfect product.

\section{References}

Arikunto, S. (2006). Prosedur Penelitian (Edisi Revisi VI). Jakarta: Rineka Cipta.

Azhar. (2004). Pengembangan Modul. Jakarta: Pusat Teknologi Informasi dan Komunikasi Pendidikan Depdiknas.

Daryanto. (2013). Menyusun Modul bahan Ajar Untuk Persiapan Guru Dalam Mengajar. Malang: Gava Media

Depdiknas. (2015). Modul pembelajaran. Diakses tanggal 12 Agustus 2015.

Depdiknas.(2008). Panduan Pengembangan Bahan Ajar. Jakarta: Depdiknas.

Dimyati, \& Mudjiono. (1999). Belajar dan Pembelajaran. Jakarta: Rajagrafindo Persada.

Hamalik. (2008). Teori Belajar dan Pembelajaran dalam pendidikan. Jakarta: Rajagrafindo Persada. 
Hamijaya. (2007). Pedoman Memilih dan Menyusun Modul. Jakarta: Gaung Persada.

Junaidi. (2011). Pengembangan Modul Pembelajaran Mata Pelajaran Sains kelas V Sekolah Dasar. Tesis Magister, tidak diterbitkan. Malang: Program Pasca Sarjana Universitas Negeri Malang.

Muliyardi. (2013). Media Pembelajaran. Jakarta: PT Raja Grafindo Persada.

Nasution. (2010). Media Pembelajaran Berupa Modul. Jakarta: Rineka Cipta.

Pupuh. (2008). Belajar dan Pembelajaran. Jakarta: Kencana.

Purwanto. (2007). Panduan Kreatif Membuat Modul Inovatif. Bandung: Remaja Rosdakarya

Sadiman, A. S., Rahardjo, R., Haryono, A., \& Rahardjito. (2007). Media Pendidikan. Jakarta: Rajagrafindo Persada.

Slameto. (2010). Belajar dan Pembelajaran. Jakarta: Rineka Cipta.

Sugiyono. (2014). Model Penelitian Kuantitatif, Kualitatif dan R\&D. Bandung: Alfabeta.

Sukmawati, \& Aisyah. (2012). Pengembangan Media Interaktif Mata Pelajaran Fisika Pokok Bahasan Listrik Statis Pada Kelas XII di Sekolah Menengah Atas Negeri 2. Tesis Program Magister Teknologi Pendidikan Program Pascasarjana Universitas Diponegoro (tidak dipublikasikan).

Zulkarnain. (2009). Pembelajaran dengan Bahan Ajar Buatan Guru. Retrieved from http://zulkarnainidiranwordpress.com/2009/06/28/pembelajaran-dengan-bahan-ajar-buat-an-guru/

\section{Copyrights}

Copyright for this article is retained by the author(s), with first publication rights granted to the journal.

This is an open-access article distributed under the terms and conditions of the Creative Commons Attribution license (http://creativecommons.org/licenses/by/4.0/). 